\title{
Prevalence of abnormalities of electrocardiogram in old people
}

\author{
A. Campbell, F. I. Caird, and T. F. M. Jackson \\ From Hairmyres Hospital, Lanarkshire; Department of Geriatric Medicine, University of Glasgow; and Health \\ Department, Burgh of East Kilbride
}

The electrocardiograms of 2254 people aged 65 or over and living at home have been classified according to the Minnesota code.

62 per cent of records showed no significant abnormality. The proportion was slightly less in men than in women, and fell sharply with age.

$Q / Q S$ patterns were seen in 6 per cent, twice as commonly in men as in women. ST-T abnormalities (8\%) were commoner in women, as were left ventricular hypertrophy patterns ( $9 \%)$.

The most frequent conduction defects were left bundle-branch block, right bundle-branch block, left anterior hemiblock, and incomplete right bundle-branch block, each of which was present in $1 \cdot 4-2 \cdot 0$ per cent.

Atrial fibrillation was present in 2 per cent under the age of 75, and 5 per cent over that age.

The findings are discussed in the light of other studies of random samples of old people.

A Community Health Service for the Elderly was set up in October 1970 in Scotland's first new town, East Kilbride, which has a total population of 67,000 . Health visitors and home nurses attached to the Burgh Health Department visit people aged 65 and over on the lists of each general practitioner, and complete a simple structured questionnaire, which incorporates questions on physical symptoms and environmental factors. Each person who agrees to participate is invited to attend a clinic where a physical examination is carried out by his own general practitioner or by a Local Authority Medical Officer, a standard 12-lead electrocardiogram is recorded, and the peak expiratory flow rate measured (Wright and McKerrow, 1959).

Most investigations of the frequency of abnormalities of the electrocardiogram in old age have been based on groups of elderly hospital patients or residents in institutions (Wosika et al., 1950; Fisch et al., 1957; Taran and Szilagyi, 1958; Mihalick and Fisch, 1974), and there have been relatively few studies of fit old people living at home (Ostrander et al., 1965; Kennedy and Caird, 1972; Kitchin, Lowther, and Milne, 1973; Martin and Millard, 1973). The present paper describes the electrocardiographic findings in over 2000 old people who attended clinics in the first three years

Received I May 1974. of operation of the East Kilbride Community Health Service for the Elderly, and takes advantage of the standardization of electrocardiographic reporting provided by the Minnesota Code (Blackburn et al., 1960; Rose and Blackburn, 1968).

\section{Methods}

Between October 1970 and October I973 technically adequate electrocardiograms have been recorded on 2254 participants, whose age and sex are shown in Table $I$. Two observers with experience of electrocardiography independently classified each electrocardiogram according to the Minnesota Code (Blackburn et al., 1960), as modified by Rose and Blackburn (1968). Disagreements occurred in about 15 per cent of cases, and were resolved by joint re-examination of the record.

The following modifications of the code were employed:

I) Records showing left axis deviation (Code II.I) were divided into those which did and did not fulfil the criteria of Rosenbaum, Elizari, and Lazzari (1970) for left anterior hemiblock. To allow for the identification of the combination of right bundle-branch block and left anterior hemiblock Code II.I was recorded in the presence of right bundle-branch block (Code VII.2).

2) The following codes were not employed: III.2 (high amplitude $\mathbf{R}$ waves in right praecordial leads), V.4 (optional code for low amplitude T waves), VIII.o (combinations of arrhythmias), and IX.O (combination of miscellaneous items). 
TABLE I Age and sex of subjects

\begin{tabular}{|c|c|c|c|c|c|c|c|c|c|}
\hline & Age group & $65-69$ & $70-74$ & $75-79$ & $80-84$ & $85+$ & $65-74$ & $75+$ & Total \\
\hline $\begin{array}{l}\text { Men: } \\
\text { Women: }\end{array}$ & $\begin{array}{l}\text { No. } \\
\text { Population* } \\
\text { Per cent of population } \\
\text { No. } \\
\text { Population } \\
\text { Per cent of population }\end{array}$ & $\begin{array}{r}507 \\
605 \\
84 \\
698 \\
910 \\
77\end{array}$ & $\begin{array}{r}225 \\
390 \\
58 \\
406 \\
705 \\
58\end{array}$ & $\begin{array}{r}93 \\
215 \\
43 \\
197 \\
455 \\
42\end{array}$ & $\begin{array}{r}38 \\
105 \\
36 \\
63 \\
215 \\
29\end{array}$ & $\begin{array}{r}9 \\
30 \\
30 \\
18 \\
80 \\
23\end{array}$ & $\begin{array}{r}732 \\
995 \\
73 \\
1104 \\
1615 \\
69\end{array}$ & $\begin{array}{r}140 \\
350 \\
40 \\
278 \\
750 \\
37\end{array}$ & $\begin{array}{r}872 \\
1345 \\
65 \\
1382 \\
2365 \\
58\end{array}$ \\
\hline Total no & & 1205 & 631 & 290 & IOI & 27 & 1836 & 418 & 2254 \\
\hline
\end{tabular}

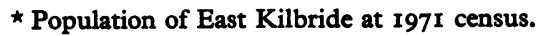

3) Records showing clockwise rotation (Code IX.4.2) were divided into those where the transition zone was to the right of lead $\mathrm{V}_{5}$, and those where it was in lead $\mathrm{V}_{4}$, between leads $\mathrm{V}_{4}$ and $\mathrm{V}_{5}$, or in lead $\mathrm{V}_{5}$.

Patterns or groups of codings were assigned according to the following definitions:

I) Minor abnormality: the following, when present alone or in combination with each other: left axis deviation (Code II.I) without left anterior hemiblock; counterclockwise rotation (Code IX.4.I); clockwise rotation (Code IX.4.2), with the transition zone in or to the left of lead V5; sinus tachycardia (Code VIII.7); sinus bradycardia (Code VIII.8). These codes were ignored when occurring in combination with others.

2) Q/QS patterns: Codes I.I.I-7 (subdivided into those with these codes alone, those with ST-T changes only, and those with other codes) were termed $Q / Q S I$ patterns, Codes I.2.I-7 and I.3.I-6 (similarly subdivided), Q/QS2 and Q/QS 3 patterns, respectively.

3) ST-T patterns: codes V.I and V.2, with or without codes IV.I-4 and in the absence of Q/QS or left ventricular hypertrophy patterns were termed major ST-T patterns. Code IV.4 alone and code V.3 with or without codes IV.I-3, and with the same exceptions, were termed minor ST-T patterns.

4) Left ventricular hypertrophy patterns: high amplitude $\mathbf{R}$ waves (codes III.I and III.3) without ST-T changes were defined as 'possible' left ventricular hypertrophy patterns, and those with ST-T changes (whatever other codes were also present) 'probable' left ventricular hyertrophy patterns (Kannel et al., 1970; Kennedy and Caird, 1972).

5) Patterns taken to indicate right ventricular hypertrophy are described in the text.

\section{Results}

The frequency of abnormalities codable in the various major groupings of the code are shown in Table 2. No codable abnormality (Code I.0) was present in 910 of the 2254 records (40\%), slightly more often in women than in men, and fell sharply in frequency, from 40 to 45 per cent in those aged under 75 , to 26 to 29 per cent in those over that age (Table 2).
492 records $(22 \%)$ showed minor abnormality as defined. Counterclockwise rotation contributed half of these ( $11 \%$ ), and clockwise rotation almost a quarter ( $5 \%$ ). Left axis deviation was found in 3 per cent. Except that 18 of the 22 subjects with sinus tachycardia were women, no subgroup showed any substantial sex difference, nor were there any clear trends with age. If the subjects with minor abnormality are added to those with no codable abnormality, then 62 per cent of all records may be said to show no significant abnormality.

The Q/QS patterns are detailed in Table 3. Forty two subjects (I.9\%) had Q/QSI patterns, $64(2.8 \%)$ $\mathrm{Q} / \mathrm{QS2}$ patterns, and $36(\mathrm{I} \cdot 6 \%) \mathrm{Q} / \mathrm{QS} 3$ patterns. $\mathrm{Q} / \mathrm{QSI}$ patterns were present in 4 per cent of men, but only 0.4 per cent of women, without relation to age. By contrast, $Q / Q S_{2}$ and 3 patterns showed a more nearly equal prevalence by sex, and some increase in frequency with age. In about one-quarter of cases Q/QS patterns were associated with patterns other than ST-T in type.

ST-T patterns, apart from those which were part of $\mathrm{Q} / \mathrm{QS}$ or left ventricular hypertrophy patterns, were found in 293 subjects (13\%) (Table 4). Major ST-T patterns were equally common in men and women $(5 \%)$, and increased in frequency with age. Minor patterns also increased in frequency with age, but were more common in women (9\%) than in men $(6 \%)$.

The frequency of ventricular hypertrophy patterns is shown in Table 5. 'Possible' left ventricular hypertrophy was found in 4 per cent, without great age or sex differences, but 'probable' left ventricular hypertrophy patterns were more frequent in women than in men, and increased in frequency with age, so that they were seen in no less than ro per cent of women over the age of 75 .

Patterns thought to indicate right ventricular hypertrophy were seen in only 16 subjects, II of them men under the age of 75 (Table 5). All I6 had cough and/or phlegm for more than three months in 
TABLE 2 Frequency of codable abnormalities

\begin{tabular}{|c|c|c|c|c|c|c|c|c|}
\hline $\begin{array}{l}\text { Age group } \\
\text { Sex }\end{array}$ & & $\begin{array}{l}65-74 \\
M\end{array}$ & $F$ & $\begin{array}{l}75+ \\
M\end{array}$ & $F$ & $\begin{array}{l}65+ \\
M\end{array}$ & $F$ & $\begin{array}{l}65+ \\
M+F\end{array}$ \\
\hline \multirow[t]{2}{*}{ Total no. } & & 732 & 1104 & 140 & 278 & 872 & 1382 & 2254 \\
\hline & Code & & & & & & & \\
\hline No codable abnormality & I.0 & 293 & 498 & 36 & 83 & 329 & 581 & 910 \\
\hline$\%$ & & 40 & 45 & 26 & 29 & 38 & 42 & $40 \cdot 3$ \\
\hline Q/QS patterns & I. $1-3$ & 69 & 37 & 18 & 18 & 87 & 55 & 142 \\
\hline$\%$ & & 9 & 3 & 13 & 6 & 10 & 4 & $6 \cdot 3$ \\
\hline QRS axis deviation & II.I-5 & 99 & 78 & 34 & 37 & 133 & IIs & 248 \\
\hline & & 14 & 7 & 24 & 13 & 15 & 8 & II $\cdot 0$ \\
\hline High amplitude $\mathbf{R}$ waves & III.I + 3 & $5 \mathrm{I}$ & 94 & 7 & 47 & 58 & I4I & 199 \\
\hline$\%$ & & 7 & 9 & 5 & 17 & 7 & IO & $8 \cdot 8$ \\
\hline $\begin{array}{l}\text { ST junction and segment } \\
\text { depression }\end{array}$ & IV.I-4 & 34 & 55 & 13 & 37 & 47 & 92 & 139 \\
\hline$\%$ & 17.4 & 5 & 5 & 9 & 13 & 5 & 7 & $6 \cdot 2$ \\
\hline T wave items & V.I-3 & 133 & 197 & 34 & 81 & 167 & 178 & 345 \\
\hline$\%$ & & 18 & 18 & 24 & 29 & 19 & 13 & $15 \cdot 3$ \\
\hline AV conduction defects & VI.I-5 & 5 & 8 & 8 & 4 & 13 & 12 & 25 \\
\hline$\%$ & & I & $\mathbf{I}$ & 6 & $\mathbf{I}$ & 2 & $\mathbf{I}$ & $\mathbf{I} \cdot \mathbf{I}$ \\
\hline Ventricular conduction defects & VII.I-6 & 46 & 45 & 16 & 14 & 62 & 59 & II I \\
\hline$\%$ & & 7 & 4 & I I & 5 & 7 & 4 & $4 \cdot 9$ \\
\hline Arrhythmias & VIII.I-8 & 48 & 70 & I7 & 39 & 65 & 109 & 174 \\
\hline$\%$ & & 7 & 6 & 12 & 14 & 8 & 9 & $7 \cdot 7$ \\
\hline Miscellaneous items & IX.I-5 & 225 & 276 & 36 & 99 & 261 & 365 & 626 \\
\hline$\%$ & & 31 & 25 & 26 & 31 & 30 & 26 & $27 \cdot 8$ \\
\hline
\end{tabular}

the year, most for many years, and all had substantial reduction in peak expiratory flow rate. Ten had right axis deviation (Codes II.2 or 3), 2 tall P waves (Code IX.3), 3 incomplete right bundlebranch block, and II clockwise rotation, with the transition zone to the left of lead $V_{5}$ in 5.
There were $2 \mathrm{I}$ examples of first degree atrioventricular block $(0.9 \%)$, together with one of $2: 1$ block (Table 6). One of the three women with a short PR interval (Code VI.5) gave a history suggestive of paroxysmal tachycardia. The commonest variety of ventricular conduction defect was left

TABLE $3 Q / Q S$ patterns

\begin{tabular}{|c|c|c|c|c|c|c|c|c|c|}
\hline & $\begin{array}{l}\text { Age group } \\
\text { Sex }\end{array}$ & & $\begin{array}{l}65-74 \\
M\end{array}$ & $F$ & $\begin{array}{l}75+ \\
M\end{array}$ & $F$ & $\begin{array}{l}65+ \\
M\end{array}$ & $F$ & $\begin{array}{l}65+ \\
M+F\end{array}$ \\
\hline & Total no. & & 732 & $I I 04$ & 140 & 278 & 872 & 1382 & 2254 \\
\hline \multirow{7}{*}{ Q/QS.I } & & Code & & & & & & & \\
\hline & Alone & I.I.I-7 & 3 & $\circ$ & I & 0 & 4 & 0 & 4 \\
\hline & With ST-T changes alone & & 19 & 4 & I & 0 & 20 & 4 & 24 \\
\hline & With other changes & & 9 & $\circ$ & 4 & $\mathbf{I}$ & 13 & $\mathbf{I}$ & 14 \\
\hline & Total & & 31 & 4 & 6 & $\mathbf{I}$ & 37 & 5 & 42 \\
\hline & $\%$ & & 4 & 0.4 & 4 & 0.4 & 4 & 0.4 & $1 \cdot 9$ \\
\hline & Alone & I.2.1-8 & 9 & 5 & $\mathbf{I}$ & 6 & Io & I I & $2 \mathbf{I}$ \\
\hline \multirow{4}{*}{ Q/QS.2 \{} & With ST-T changes alone & & 14 & 12 & 4 & 3 & 18 & 15 & 33 \\
\hline & With other changes & & 2 & 3 & $\mathbf{I}$ & 4 & 3 & 7 & Io \\
\hline & Total & & 25 & 20 & 6 & 13 & 31 & 33 & 64 \\
\hline & $\%$ & & 3 & 2 & 4 & 5 & 3 & 2 & $2 \cdot 8$ \\
\hline \multirow{5}{*}{ Q/QS.3 } & Alone & I.3.I-6 & 6 & 6 & 2 & 2 & 8 & 8 & 16 \\
\hline & With ST-T changes alone & & 4 & 3 & 2 & $\mathbf{I}$ & 6 & 4 & 10 \\
\hline & With other changes & & 3 & 4 & 2 & $\mathbf{I}$ & 5 & 5 & I0 \\
\hline & Total & & 13 & 13 & 6 & 4 & 19 & 17 & 36 \\
\hline & $\%$ & & 2 & $\mathbf{I}$ & 4 & $\mathbf{I}$ & 2 & $\mathbf{I}$ & $1 \cdot 6$ \\
\hline Q/QS & $\begin{array}{l}\text { Total } \\
\%\end{array}$ & I. I-3 & $\begin{array}{r}69 \\
9\end{array}$ & $\begin{array}{r}37 \\
3\end{array}$ & $\begin{array}{l}18 \\
13\end{array}$ & $\begin{array}{r}18 \\
6\end{array}$ & $\begin{array}{l}87 \\
\text { I0 }\end{array}$ & $\begin{array}{r}55 \\
4\end{array}$ & $\begin{array}{r}142 \\
6.3\end{array}$ \\
\hline
\end{tabular}


TABLE $4 S T$ - $T$ patterns

\begin{tabular}{|c|c|c|c|c|c|c|c|c|c|}
\hline & $\begin{array}{l}\text { Age group } \\
\text { Sex }\end{array}$ & & $\begin{array}{l}65-74 \\
M\end{array}$ & & $\begin{array}{l}75+ \\
M\end{array}$ & $F$ & $\begin{array}{l}65+ \\
M\end{array}$ & $F$ & $\begin{array}{l}65+ \\
M+F\end{array}$ \\
\hline & Total no. & & 732 & 1104 & 140 & 278 & 872 & 1382 & 2254 \\
\hline $\begin{array}{c}\text { Major ST-T } \\
\text { patterns }\end{array}$ & $\left\{\begin{array}{l}\text { Alone } \\
\text { With other changes } \\
\text { Total } \\
\%\end{array}\right.$ & $\begin{array}{l}\text { Code } \\
\text { V.I or } 2 \\
\pm \text { IV.I }-4\end{array}$ & $\begin{array}{r}23 \\
7 \\
30 \\
4\end{array}$ & $\begin{array}{r}44 \\
6 \\
50 \\
5\end{array}$ & $\begin{array}{r}8 \\
4 \\
12 \\
9\end{array}$ & $\begin{array}{r}18 \\
1 \\
19 \\
7\end{array}$ & $\begin{array}{r}31 \\
11 \\
42 \\
5\end{array}$ & $\begin{array}{r}62 \\
7 \\
69 \\
5\end{array}$ & $\begin{array}{r}93 \\
18 \\
111 \\
5\end{array}$ \\
\hline$\underset{\text { patterns }}{\text { Minor ST-T }}$ & $\left\{\begin{array}{l}\text { Alone } \\
\text { With other changes } \\
\text { Total } \\
\%\end{array}\right.$ & $\begin{array}{l}\text { V. } 3 \pm \text { IV.I-3 } \\
\text { or IV.4 }\end{array}$ & $\begin{array}{r}37 \\
8 \\
45 \\
6\end{array}$ & $\begin{array}{r}80 \\
13 \\
93 \\
8\end{array}$ & $\begin{array}{r}11 \\
0 \\
11 \\
8\end{array}$ & $\begin{array}{r}26 \\
7 \\
33 \\
12\end{array}$ & $\begin{array}{r}48 \\
8 \\
56 \\
6\end{array}$ & $\begin{array}{r}106 \\
26 \\
126 \\
9\end{array}$ & $\begin{array}{r}154 \\
28 \\
182 \\
8\end{array}$ \\
\hline
\end{tabular}

^ Excluding subjects with Q/QS or left ventricular hypertrophy patterns.

anterior hemiblock, which was present in 51 subjects $(2 \%)$, 15 of whom also had right bundlebranch block (Table 6). Left anterior hemiblock was commoner in men than women. Complete left bundle-branch block was found in 3I subjects ( $1.4 \%)$, again more commonly in men, and complete right bundle-branch block in 40 ( $1.9 \%)$. There were 32 examples of incomplete right bundle-. branch block ( $1 \cdot 4 \%$ ), II of intraventricular block, and 7 of incomplete left bundle-branch block.

The only arrhythmias commonly observed were frequent ectopic beats (defined as more than 4 ectopic complexes in 40), and atrial fibrillation (Table 7). Sixty-nine subjects $(3 \%)$ had frequent ectopic beats, which were atrial in origin in 3I, ventricular in 27, nodal in 3 , and mixed in 8 . Atrial fibrillation was present in 2 per cent of records from subjects under 75 and 5 per cent over that age. Six examples of low atrial or coronary sinus rhythm (Code VIII.6) were encountered.

Thirty-three subjects showed a variety of miscellaneous abnormalities occurring in isolation. These include one possible example of left posterior hemiblock (Code II.3), I4 of low amplitude QRS complexes (Code IX.I), 3 each of ST segment elevation (Code IX.2), and tall T waves (Code IX.5), 6 of tall $P$ waves of ' $P$ pulmonale' type (Code IX. 3; 4 of these subjects had chronic bronchitis), and finally 5 with clockwise rotation with the transition zone to the left of lead V5 (Code IX.4.2), without obvious explanation, such as anterior infarction, right ventricular hypertrophy, or left anterior hemiblock.

TABLE 5 Ventricular hypertrophy patterns

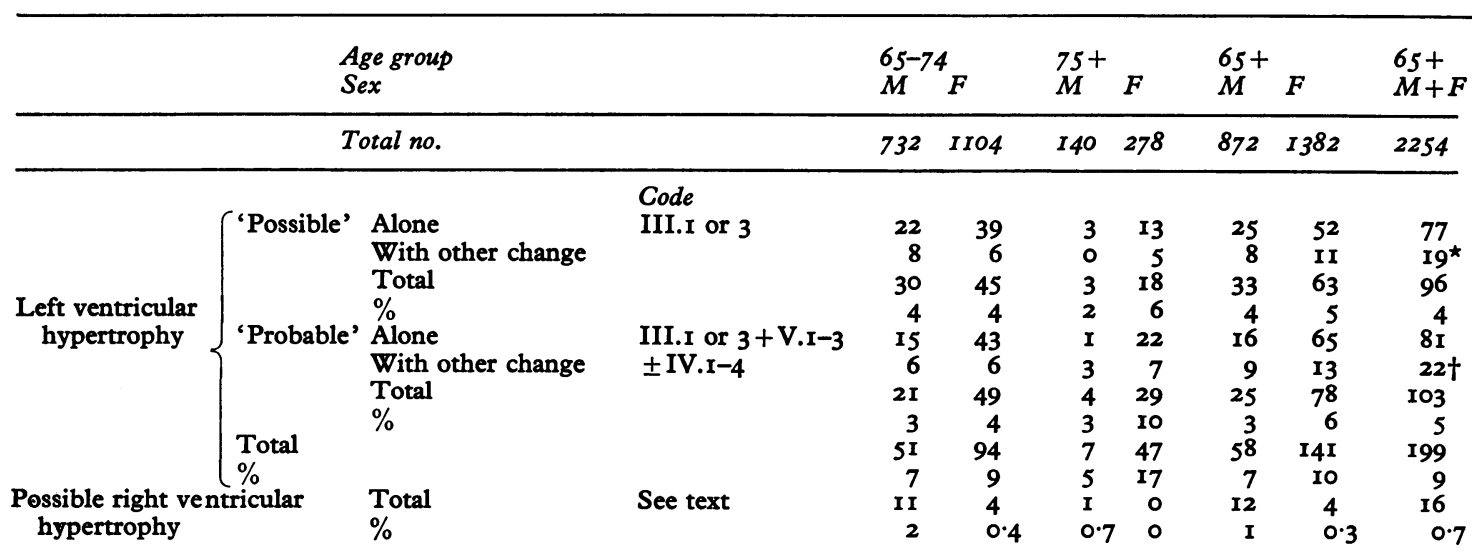

* 3 with $\mathrm{Q} / \mathrm{QS}$ patterns.

† 9 with Q/QS patterns. 
TABIE 6 Conduction defects

\begin{tabular}{|c|c|c|c|c|c|c|c|c|c|}
\hline & \multicolumn{2}{|l|}{$\begin{array}{l}\text { Age group } \\
\text { Sex }\end{array}$} & \multicolumn{2}{|c|}{$\stackrel{65}{M-74}^{6} F$} & \multirow{2}{*}{$\begin{array}{l}75+ \\
M \\
140\end{array}$} & \multirow{2}{*}{$\frac{F}{278}$} & \multicolumn{2}{|c|}{$\stackrel{65}{M}^{+} F$} & $\begin{array}{l}65+ \\
M+F\end{array}$ \\
\hline \multicolumn{3}{|c|}{ Total no. } & 732 & 1104 & & & 872 & 382 & 2254 \\
\hline \multirow[t]{4}{*}{$\begin{array}{l}\text { Atrio- } \\
\text { ventricular }\end{array}$} & $\left\{\begin{array}{l}\text { Ist degree atrioventricular block } \\
\text { Other }\end{array}\right.$ & $\begin{array}{l}\text { Code } \\
\text { VI.3 } \\
\text { VI.2 and } 5\end{array}$ & $\begin{array}{l}5 \\
0\end{array}$ & $\begin{array}{l}4 \\
4\end{array}$ & $\begin{array}{l}8 \\
0\end{array}$ & $\begin{array}{l}4 \\
0\end{array}$ & $\begin{array}{r}13 \\
0\end{array}$ & $\begin{array}{l}8 \\
4\end{array}$ & $4^{\text {2I }}$ \\
\hline & $\left\{\begin{array}{l}\text { Left bundle-branch block } \\
\% \\
\text { Right bundle-branch block alone } \\
\text { Right bundle-branch block with }\end{array}\right.$ & $\begin{array}{l}\text { VII.I } \\
\text { VII.2 }\end{array}$ & $\begin{array}{r}12 \\
2 \\
8\end{array}$ & $\begin{array}{r}13 \\
1 \\
10\end{array}$ & $\begin{array}{l}2 \\
1 \\
3\end{array}$ & $\begin{array}{l}4 \\
1 \\
4\end{array}$ & $\begin{array}{r}14 \\
2 \\
11\end{array}$ & $\begin{array}{r}17 \\
1 \\
14\end{array}$ & $\begin{array}{r}31 \\
1 \\
25\end{array}$ \\
\hline & left anterior hemiblock & II.I, VII.2 & 8 & $\mathbf{I}$ & 5 & $I_{5}$ & 13 & 2 & 15 \\
\hline & $\%$ & & 2 & $\mathbf{I}$ & $\begin{array}{l}8 \\
6\end{array}$ & $\begin{array}{l}5 \\
2\end{array}$ & $\begin{array}{r}24 \\
3\end{array}$ & $\begin{array}{r}10 \\
1\end{array}$ & $\begin{array}{r}40 \\
2\end{array}$ \\
\hline \multirow[t]{6}{*}{ Ventricular } & Left anterior hemiblock & II.I & 18 & 7 & 4 & 7 & 22 & 14 & 36 \\
\hline & $\begin{array}{l}\% \\
\text { Incomplete left bundle-branch }\end{array}$ & & 2 & $\mathbf{I}$ & 3 & 2 & 3 & $\mathbf{I}$ & 2 \\
\hline & $\begin{array}{l}\text { block } \\
\text { Incomplete right bundle-branch }\end{array}$ & VII.6 & 2 & 3 & $\mathbf{I}$ & $\mathbf{I}$ & 3 & 4 & 7 \\
\hline & block & VII:3 & 12 & I6 & 2 & 2 & 14 & 18 & 32 \\
\hline & $\%$ & & 2 & $\mathbf{I}$ & $\mathbf{I}$ & $\mathbf{I}$ & 2 & $\mathbf{I}$ & $\mathbf{I}$ \\
\hline & Intraventricular block & VII.4 & 4 & 2 & 3 & 2 & 7 & 4 & II \\
\hline
\end{tabular}

* I case of 2:I atrioventricular block, and 3 of short PR interval. Subjects with other abnormalities included.

\section{Discussion}

The subjects of this study comprise a proportion of the total elderly population of East Kilbride, which declines with age (Table I). The likely reasons for this are the continuing recruitment into the screening programme of people reaching the age of 65 , and the selective exclusion of those old people who are unable or unwilling to attend for examination at a clinic; these are likely to be more frequent in the older age groups. Thus, though other more truly random samples of the elderly population (Kennedy and Caird, 1972; Kitchin et al., 1973) may reflect the overall prevalence of electrocardiographic abnormalities more accurately, there can be little reason to doubt that the present subjects represent the healthier part of the elderly population.

Comparison between the findings of the present study and those of others is greatly simplified by considering principally those in which the Minnesota Code has been employed (Table 8), but there remain difficulties, especially when the problems raised by multiple codes have been solved differently by different workers. Even the definition of normality varies. The frequency of 'no codable

TABLE 7 Arrhythmias

\begin{tabular}{|c|c|c|c|c|c|c|c|c|}
\hline $\begin{array}{l}\text { Age group } \\
\text { Sex }\end{array}$ & & $\begin{array}{l}65-74 \\
M\end{array}$ & $F$ & ${ }_{M}^{75+}$ & $F$ & $\frac{65+}{M}$ & $F$ & $\begin{array}{l}65+ \\
M+F\end{array}$ \\
\hline Total no. & & 732 & $I I 04$ & 140 & 278 & 872 & 1382 & 2254 \\
\hline $\begin{array}{l}\text { Atrial fibrillation } \\
\% \\
\text { Frequent ectopic beats } \\
\% \\
\text { Coronary sinus rhythm }\end{array}$ & $\begin{array}{l}\text { Code } \\
\text { VIII.3 } \\
\text { VIII.I } \\
\text { VIII.6 }\end{array}$ & $\begin{array}{r}\mathbf{1 I} \\
2 \\
27 \\
4 \\
1\end{array}$ & $\begin{array}{r}20 \\
2 \\
2 I \\
2 \\
2\end{array}$ & $\begin{array}{l}7 \\
5 \\
8 \\
6 \\
1\end{array}$ & $\begin{array}{r}13 \\
5 \\
13 \\
5 \\
2\end{array}$ & $\begin{array}{r}18 \\
2 \\
35 \\
4 \\
2\end{array}$ & $\begin{array}{r}33 \\
2 \\
34 \\
3 \\
4\end{array}$ & $\begin{array}{l}51 \\
2 \\
69^{\star} \\
3 \\
6(0 \cdot 3 \%)\end{array}$ \\
\hline
\end{tabular}

* Atrial in 31, nodal in 3, ventricular in 27, and mixed in 8.

Subjects with other abnormalities included. 
TABLE 8 Prevalence of electrocardiographic abnormalities in old people at home

\begin{tabular}{|c|c|c|c|c|c|}
\hline Study & $\begin{array}{l}\text { Ostrander } \\
\text { et al. }(1965)^{\star}\end{array}$ & $\begin{array}{l}\text { Edmands } \\
(1966)\end{array}$ & $\begin{array}{l}\text { Kennedy and } \\
\text { Caird }(1972)^{\star}\end{array}$ & $\begin{array}{l}\text { Kitchin } \\
\text { et al. }(1973)^{\star}\end{array}$ & This study* \\
\hline $\begin{array}{l}\text { Age } \\
\text { No. of subjects }\end{array}$ & $\begin{array}{l}60+ \\
603\end{array}$ & $\underset{1560}{52+}$ & $\begin{array}{l}65+ \\
400\end{array}$ & $\begin{array}{c}62+ \\
482\end{array}$ & $\begin{array}{r}65+ \\
2254\end{array}$ \\
\hline $\begin{array}{l}\text { No codable abnormality } \\
\text { Q/QS patterns } \\
\text { T wave items } \\
\text { Left bundle-branch block } \\
\text { Right bundle-branch block } \\
\text { Incomplete right bundle-branch block } \\
\text { Atrial fibrillation }\end{array}$ & $\begin{array}{l}- \\
7 \% \\
32 \% \\
1 \cdot 7 \% \\
2 \cdot 0 \% \\
1 \cdot 7 \% \\
2 \cdot 4 \%\end{array}$ & $\begin{array}{l}- \\
\overline{-} \\
1 \cdot 4 \% \\
2 \cdot 0 \% \\
-\end{array}$ & $\begin{array}{l}43 \% \dagger \\
10 \% \\
11 \% \\
2.5 \% \\
3.5 \% \\
3.0 \% \\
3.0 \%\end{array}$ & $\begin{array}{l}44 \% \dagger \\
8 \% \\
27 \% \\
0.6 \% \\
2.3 \% \\
1.5 \% \\
2.5 \%\end{array}$ & $\begin{array}{l}40 \% \ddagger \\
6 \% \\
15 \% \\
1 \cdot 4 \% \\
1 \cdot 9 \% \\
1 \cdot 5 \% \\
2 \cdot 0 \%\end{array}$ \\
\hline
\end{tabular}

^ Minnesota code employed.

† Includes positional changes only.

‡ Excludes positional changes only.

abnormality' cannot be determined from the data of Ostrander et al. (1965), while the apparent agreement between the other three studies shown in Table 8 is in fact spurious, since 'no codable abnormality' in the present study includes only Code I.o, and in those of Kennedy and Caird (1972) and Kitchin et al. (1973) also includes codes for positional changes, which are present in over 20 per cent of cases.

There is, however, good agreement between the various investigations on the prevalence of $Q / Q S$ abnormalities, which are found in 6 to ro per cent of records (Table 8). All find them more common in men than in women, but the remarkable difference in prevalence by sex between $\mathrm{Q} / \mathrm{QSI}$ patterns on the one hand, which are ro times more frequent in men in the present study (Table 3), and Q/QS2 and 3 patterns on the other, in which the sex ratio is very much less, does not seem to have been remarked on previously. A further striking difference is seen in the prevalence of ST-T abnormalities that were found in about 30 per cent of elderly people by Ostrander et al. (1965) and Kitchin et al. (1973), but in only half that proportion by Kennedy and Caird (1972) and in the present study. All four studies find ST-T patterns more common in women than in men, especially $T$ wave flattening (Code V.3), and show an increase in frequency with age. The reason for the twofold difference in total prevalence is uncertain.

The most frequent conduction defect found in the present study is left anterior hemiblock, which was present in 2 per cent of all records, including about one-third of those with complete right bundle-branch block, as Edmands (I966) also found. It has been stated that left bundle-branch block is more common in the elderly than right bundlebranch (Bjornberg, 1960), but all five investigations cited in Table 8 show the reverse to be true. Bjornberg studied hospital patients, and it is likely that left bundle-branch block is more often associated than right bundle-branch block with severe and symptomatic heart disease in old age, and thus tends to be over represented in a hospital population.

The frequency of first degree atrioventricular block $(0.9 \%)$ is of the same order as that found by Hiss and Lamb (1962) in younger people $(0.65 \%)$, while to find only one subject with a higher degree of block among 2000 old people is not unexpected, since Shaw and Eraut (1970) give a prevalence of I per 1000 over the age of 75, and less than half that figure for ages between 65 and 75, for second and third degree heart block together.

Kannel et al. (1970) suggested that left ventricular hypertrophy patterns should be divided into 'possible', when only voltage changes are present, and 'definite' or 'probable', when ST-T changes are also seen. When this distinction is applied to the elderly (Kennedy and Caird, I972) 'possible' left ventricular hypertrophy shows little sex or age difference, while 'probable' left ventricular hypertrophy is found more commonly in women, especially over the age of 75 (Table 5). This presumably principally reflects the higher mean blood pressure of elderly women (Hamilton et al., 1954; Master, Lasser, and Jaffe, 1958; Anderson and Cowan, 1959), though 'probable' left ventricular hypertrophy patterns are not infrequently encountered in clinical practice in elderly women who have no past or present evidence of a rise in blood pressure, nor of valvular disease such as aortic stenosis.

The Minnesota Code does not provide adequately for the identification of right ventricular hypertrophy, particularly that accompanying airways obstruction (which is by far the commonest variety in old age (Kennedy and Caird, 1972)), when high 
amplitude $\mathbf{R}$ waves in the right praecordial leads are distinctly rare (Caird and Wilcken, 1962). The most satisfactory criteria are probably those of Goodwin and Abdin (1959), but these require the recording of lead $V_{4} R$, without which one-third of cases of right ventricular hypertrophy in airways obstruction will be missed (Caird and Wilcken, 1962). There is, however, little doubt that the great majority of the 16 cases recorded in Table 6 as having right ventricular hypertrophy would have satisfied the criteria of Goodwin and Abdin (1959). The striking preponderance of right ventricular hypertrophy in men parallels the much greater prevalence of chronic bronchitis in elderly men (Caird and Akhtar, 1972), while its rarity over the age of 75 reflects the poor prognosis of chronic pulmonary heart disease in old age (Bedford and Caird, 1956).

Atrial fibrillation is found in 2 to 3 per cent of electrocardiograms of old people at home (Table 8), with little sex difference, but an increase with age (Table 7). In elderly patients in hospital the prevalence is around 15 per cent (see Bedford and Caird, 1960)-a striking example of the difference between the two population groups.

Ectopic beats are very often seen in standard electrocardiograms in old age, but their frequency relatively rarely reaches $I$ in Io complexes, the figure needed for them to be recorded under the Minnesota Code. They are encountered at this frequency in only 3 per cent of records (Table 7) with little sex difference and a small increase with age. The relative frequencies of ectopic beats of atrial and ventricular origins is as previously found (Kennedy and Caird, 1972). The detection of a small number of cases of coronary sinus rhythm $(0.3 \%)$ is of interest; the prevalence is of the same order as Hiss and Lamb (1962) found in younger people $(0.55 \%)$. Clinical impression supports their view that this is a benign arrhythmia at any age.

In conclusion, this study shows that the electrocardiogram is entirely normal in 40 per cent of old people, and that only minor abnormalities are present in a further 22 per cent. Separate assessment is needed of the significance of each of the definite abnormalities shown in the remainder, and the second paper in this series will attempt this.

Our thanks are due to the general practitioners of East Kilbride for permission to study patients under their care, to the staff of the Department of the Medical Officer of Health for their untiring assistance with the records, and to Dr. R. D. Kennedy for advice and criticism.

\section{References}

Anderson, W. F., and Cowan, N. R. (1959). Arterial pressure in healthy older people. Clinical Science, 18, 103.
Bedford, P. D., and Caird, F. I. (1956). Congestive heart failure in the elderly. Quarterly fournal of Medicine, n.s. 25, 407.

Bedford, P. D., and Caird, F. I. (1960). Valvular Disease of the Heart in Old Age. Churchill, London.

Bjornberg, O. (1960). Schenkelblock bei geriatrischer Klientel. Gerontologia clinica, 2, 133.

Blackburn, H., Keys, A., Simonson, E., Rautaharju, P., and Punsar, S. (1960). The electrocardiogram in population studies: a classification system. Circulation, 21, I 160.

Caird, F. I., and Akhtar, A. J. (1972). Chronic respiratory disease in the elderly. Thorax, 27, 764.

Caird, F. I., and Wilcken, D. E. L. (I962). The electrocardiogram in chronic bronchitis with generalized obstructive lung disease. American fournal of Cardiology, 10, 5.

Edmands, R. E. (1966). An epidemiological assessment of bundle-branch block. Circulation, 34, 1081.

Fisch, C., Genovese, P. D., Dyke, R. W., Laramore, W., and Marvel, R. J. (1957). The electrocardiogram in persons over 70. Geriatrics, 12, 616.

Goodwin, J. F., and Abdin, Z. H. (1959). The cardiogram of congenital and acquired right ventricular hypertrophy. British Heart fournal, 21, 523.

Hamilton, M., Pickering, G. W., Fraser Roberts, J. A., and Sowry, G. S. C. (1954). The aetiology of essential hypertension. I: The arterial pressure in the general population. Clinical Science, I3, II.

Hiss, R. G., and Lamb, L. E. (1962). Electrocardiographic findings in 122,043 individuals. Circulation, 25, 947.

Kannel, W. B., Gordon, T., Castelli, W. P., and Margolis, J. R. (1970). Electrocardiographic left ventricular hypertrophy and risk of coronary heart disease. Annals of Internal Medicine, 72, 813.

Kennedy, R. D., and Caird, F. I. (1972). The application of the Minnesota code to population studies of the electrocardiogram in the elderly. Gerontologia clinica, 14, 5 .

Kitchin, A. H., Lowther, C. P., and Milne, J. S. (1973). Prevalence of clinical and electrocardiographic evidence of ischaemic heart disease in the older population. British Heart fournal, $35,946$.

Martin, A., and Millard, P. H. (1973). Cardiovascular assessment in the elderly. Age and Ageing, 2, 211.

Master, A. M., Lasser, R. P., and Jaffe, H. L. (1958). Blood pressure in white people over 65 years of age. Annals of Internal Medicine, 48, 284.

Mihalick, M. J., and Fisch, C. (1974). Electrocardiographic findings in the aged. American Heart fournal, 87, 117.

Ostrander, L. D., Brandt, R. L., Kjelsberg, M. O., and Epstein, F. H. (1965). Electrocardiographic findings among the adult population of a total natural community, Tecumseh, Michigan. Circulation, 31, 888.

Rose, G. A., and Blackburn, H. (1968). Cardiovascular Survey Methods. World Health Organization, Geneva.

Rosenbaum, M. B., Elizari, M. V., and Lazzari, J. O. (1970). The Hemiblocks. Tampa Tracings, Oldsmar, Florida.

Shaw, D. B., and Eraut, D. (1970). Prevalence and morbidity of heart block in Devon. British Medical fournal, 1, 144 .

Taran, L. M., and Szilagyi, H. (1958). Electrocardiographic changes with advancing age. Geriatrics, 13, 352.

Wosika, P. H., Feldman, E., Chesrow, E. J., and Myers, G. B. (1950). Unipolar precordial and limb lead electrocardiograms in the aged. Geriatrics, $5,131$.

Wright, B. M., and McKerrow, C. B. (1959). Maximum forced expiratory flow rate as a measure of ventilatory capacity. British Medical fournal, 2, 104I.

Requests for reprints to Dr. F. I. Caird, University Department of Geriatric Medicine, Southern General Hospital, Glasgow G5I 4TF. 